\title{
ĐÁNH GIÁ ĐộC TÍNH CẤP TÍNH DỊCH CAO CHIẾT ETHANOL TÙ QUẢ THỂ NẤM VÂN CHI (CORIOLOPSIS ASPERA) Ở VIẸT NAM TRÊN CHUỘT SWISS ALBINO
}

\author{
NGUYỄN NGỌC THUẦ ${ }^{1,2}$, TRẦN THI PHƯƠNG NHUNG ${ }^{1}$, NGUYỄN NGOC TUẤN ${ }^{1}$, NGUYỄN \\ THỊ NGẦN ${ }^{1}$, ĐÀO THI HUẸ ${ }^{1}$, VÕ DƯƠNG MỸ DUYÊN ${ }^{1}$, BÙI THANH HÒA ${ }^{1}$, TRÀNN THÀNH \\ ĐẠT ${ }^{1}$, LÊ TRUNG THIÊN ${ }^{2}$, ĐÀM SAO MAI ${ }^{1}$ \\ ${ }^{1}$ Viện Công nghệ Sinh học và Thưc Phẩm, Đại Học Công Nghiệp thành phố Hồ Chí Minh \\ ${ }^{2}$ Khoa Công nghệ Thực Phẩm, Đại Học Nông Lâm Thành phố Hồ Chí Minh. \\ damsaomai@iuh.edu.vn
}

Tóm tắt. Coriolopsis aspera là một loại nấm dược liệu, trong thành phần có chứa nhiều chất chống oxy hóa mạnh, giúp tăng cường hệ thống miễn dịch và chống lại một số bệnh ung thư. Nghiên cứu này nhằm mục đích kiểm tra độc tính cấp tính của chiết xuất ethanol trích ly từ quả thể nấm vân chi (Coriolopsis aspera) ở Việt Nam trên chuột Swiss albino. Các nghiên cứu được thực hiện với các liều cố định là 2000, 4000 và $6000 \mathrm{mg} / \mathrm{kg}$ thể trọng thông qua đường uống hàng ngày. Các dấu hiệu độc tính về hành vi và tỷ lệ tử vong được ghi nhận sau mỗi hai giờ cho đến 24 giờ dùng thuốc đối với độc tính cấp tính và tiếp tục sử dụng các chất chiết xuất cho đến 14 ngày để phân tích các thông số vật lý, sinh hóa, huyết học và nghiên cứu mô bệnh học ở tim, gan, thận. Liều cao nhất được sử dụng không gây tử vong hoặc thay đổi hành vi chung của động vật thử nghiệm. Tất cả các thông số không thay đổi trong suốt nghiên cứu. Những kết quả này cho thấy sự an toàn của việc uống chiết xuất từ quả thể nấm.

Từ khóa: Coriolopsis aspera, độc tính cấp tính, swiss albino.

\section{ACUTE TOXICITY ASSESSMENT OF THE ETHANOL EXTRACT FROM FRUITING MASSES OF YUNZHI MUSHROOMS (CORIOLOPSIS ASPERA) IN VIETNAM IN SWISS ALBINO MICE}

\begin{abstract}
Coriolopsis aspera is a medicinal mushroom, it contains a variety of powerful antioxidants and other compounds that help boost immune system and fight certain cancers. This study aims to test the acute toxicity of the ethanolic extract from fruiting masses of Turkey tails (Coriolopsis aspera) in Siss albino mice. Studies were carried out with a fixed dose of 2000, 4000, and $6000 \mathrm{mg} / \mathrm{kg}$ body weight through oral administration daily. In terms of behavior and mortality, signs of toxicity were noted after every two hours to 24 hours in an acute toxicity test. The test Swiss albino mice were continued to use the Coriolopsis aspera ethanolic extracts for up to 14 days. The physical, biochemical, hematological parameters of the mice were analyzed and the histopathological of heart, liver, kidney were studied. The results showed that the highest dose used did not cause death or change test animals' general behavior. All parameters were unaltered throughout the stude. The present study revealed no obvious toxicity in mice treated with Coriolopsis aspera. These results indicate the safety of the oral administration of fruiting masses extract.
\end{abstract}

Keywords. Coriolopsis aspera, acute toxicity, swiss albino, the ethanol extract from fruiting masses of turkey tails

\section{GIỚI THIỆU}

Coriolopsis sp thuộc giới Fungi, ngành Basidiomycota, lớp Agaricomycetes, bộ Polyporales, họ Polyporaceae, chi Coriolopsis. Các chi Coriolopsis, Artolenzites, Coriolus, Cubamyces, Cyclomycetella, Lenzites, Poronidulus, Pseudotrametes, Pycnoporus và chi Trametes giống nhau [1]. Các loài thuộc chi Coriolopsis sp là loại nấm lớn thuộc họ nấm lỗ có màu nâu thường mộc trên gỗ đã chết. Loài này được phân bố rộng trên Thế Giới như ở Bắc Mỹ, Châu Phi, Nam và Trung Âu và Châu Á. Ở Việt Nam loài này đã được phát hiện ở rừng Cúc Phương, Pù Mát-Nghệ An, Tam Đảo. Đây là loài nấm hoại sinh gây mục trắng ở gỗ cứng, quả thể có kích thước trung bình từ 3-8 x 2-9 x 0,3-1cm [2]. Trong thành phần loài này chứa các hợp chất hoạt tính sinh học phong phú, bao gồm terpenoids, steroid, phenol, nucleotide, dẫn xuất 
glycoprotein và polysacarides [3,4]. Chi Coriolopsis chưa được nghiên cứu nhiều, trong đó có loài Coriolopsis aspera. Hiện nay, xu hướng ứng dụng dịch cao chiết từ nguyên liệu tự nhiên để sử dụng trong lĩnh vực dược, $\mathrm{y}$ học và thực phẩm ngày càng nhiều trong đó có các loài nấm vân chi. Nguyên nhân trong dịch cao chiết có chứa những chất có khả năng chống oxy hóa, kháng viêm, kháng ung thư $[5,6]$. Nhiều nghiên cứu gần đây đã cho thấy thành phần dịch cao chiết nấm vân chi ly trích từ dung môi ethanol hay methanol có chứa các nhóm chất terpenoids, saponins, steroids, flavonoids, phenols, tannins, alkaloids [3, $7,8]$. Ngoài ra, dịch chiết ethanol của nấm vân chi còn có tác dụng kích thích hệ miễn dịch và chống oxy hóa do đó có thể được sử dụng cho thực phẩm bỗ sung dinh dưỡng $[9,10]$. Gần đây, Nguyen và cộng sự (2020), nấm Coriolopsis aspera có hoạt tính chống oxy hóa, khả năng kháng viêm, khả năng gây độc tế bào ung thư gan và tế bào ung thư cổ tử cung [11]. Trong các nghiên cứu về nấm Coriolopsis aspera chưa thấy có công trình báo cáo về độc tính của dịch cao chiết ethanol từ quả thể. Chính vì lý do đó chúng tôi lần đầu tiên nghiên cứu đánh giá độc tính cấp tính dịch cao chiết ethanol từ quả thể nấm Coriolopsis aspera ở Việt Nam trên đối tượng chuột swiss albino nhằm mục đích làm cơ sở ứng dụng dịch cao chiết ethanol trong lĩnh vực chế thực phẩm có lợi cho sức khỏe.

\section{VẬT LIÊUU VÀ PHƯƠNG PHÁP NGHIÊN CỨU}

\subsection{Nguyên liệu}

Nấm vân chi Coriolopsis aspera tự nhiên được thu nhận tại vườn Quốc Gia Pù Mát nằm ở 1846' vĩ độ Bắc và 104²4' độ kinh Đông thuộc tỉnh Nghệ An.

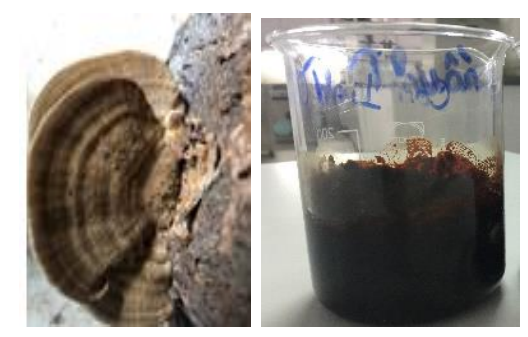

Hình 1: Quả thể và dịch cao chiết ethanol của nấm Coriolopsis aspera

\subsection{Chuẩn bị dịch cao chiết ethanol nấm Coriolopsis aspera (EtCA)}

Quả thể nấm vân chi $C$. aspera được chiết xuất bằng ethanol $(\mathrm{EtOH})$ thực phẩm với các thông số tối ưu để đạt hàm lượng triterpen $2,09 \mathrm{mg}$ axit oleanolic/g DW, có hỗ trợ siêu âm (UAE) và nitơ lỏng để phá vỡ tế bào nguyên liệu [11]. Dịch chiết thu được (EtCA) cho bay hơi dung môi dưới áp suất chân không ở nhiệt độ $40^{\circ} \mathrm{C}$ bằng thiết bị cô quay chân không IKA của Đức. Dung dịch này được đem cô đặc làm giàu TTC đến 130,3 mg acid oleanolic/g DW.

\section{3. Đối tượng nghiên cứu}

Chuột nhắt trắng Swiss albino được cung cấp bởi viện Pasteur TP.HCM. Chuột được nuôi trong phòng, cho ăn được duy trì ở nhiệt độ cụ thể $\left(23 \pm 3^{\circ} \mathrm{C}\right)$, độ ẩm tương đối $(55 \pm 15 \%)$, tần số thông gió $(10-20$ lần/h) và chiếu sáng (12 giờ; từ 8 giờ sáng đến 8 giờ tối). Chuột được chọn ngẫu nhiên, chia thành các nhóm thí nghiệm và đối chứng. Nuôi nhốt trong lồng nuôi đã khử trùng, lồng chứa dăm gỗ làm chất độn chuồng. Chuột được ăn thức ăn viên tiêu chuẩn như và uống nước lọc. Tất cả các quy trình thử nghiệm đều tuân thủ theo các nguyên tắc được quốc tế chấp nhận về việc sử dụng và chăm sóc động vật trong phòng thí nghiệm. Quy trình thử nghiệm tuân thủ nghiêm ngặt theo Tuyên bố Helsinki, 1975 [12].

\subsection{Thử độc tính cấp tính của dịch chiết nấm Coriolopsis aspera}

Sử dụng phương pháp Lorke (1983) và Miller (1944) có chỉnh sửa [13,14]. Quy trình thử độc tính cấp tính trên chuột được tiến hành theo hướng dẫn 407 (2001) của OECD [15] và hướng dẫn thử nghiệm tiền lâm sàng và lâm sàng thuốc đông $\mathrm{y}$, thuốc từ dược liệu theo quyết định số 141/QĐ-K2ĐT ngày 27/10/2015 của Cục trưởng Cục Khoa học Công nghệ và Đào tạo, Bộ Y tế, Việt Nam. 
Thử nghiệm trên chuột Swiss albino và sắp xếp thành 4 nhóm, mỗi nhóm 6 con. Những con chuột đối chứng được cho uống nước lọc (10 ml/kg/trọng lượng cơ thể) [16], 4 nhóm còn lại được uống EtCA với liều lần lượt là 2000,4000 và $6000 \mathrm{mg} / \mathrm{kg}$ thể trọng $[17,18]$. Nước lọc và thuốc thử đuợc đưa vào dạ dày chuột bằng kim cong đầu tù, cho uống liên tục trong 7 ngày [19]. Tất cả chuột sau khi uống dịch chiết được phép tiếp cận tự do với thức ăn và nước uống. Việc quan sát các dấu hiệu nhiễm độc được thực hiện 1,2 và 4 giờ sau khi điều trị và định kỳ trong 24 giờ đầu tiên. Tỷ lệ tử vong và các phát hiện trong phòng thí nghiệm bao gồm sự thay đổi về màu sắc của da, mắt, màng nhầy được ghi lại trong vòng 4 giờ đầu tiên. Trong 7 ngày tiếp theo, quan sát tư thế cơ thể, chuyển động, đứng, nằm, chấn động, sự hấp thụ, cơn đau, phản ứng chậm, phản xạ đi lại, hành vi (tiết nước bọt, hôn mê), bất kỳ thương tích hoặc bệnh tật nào, tỷ lệ tử vong v.v. được tiến hành quan sát một lần/ngày trong 14 ngày và được ghi lại cẩn thận. Ngoài ra, chế độ ăn uống cũng được quan sát và ghi chép [20]. Hàng ngày, trong hai tuần sau khi thực hiện thí nghiệm được quan sát liên tục và ghi chép đầy đủ. Tìm liều cao nhất chuột không chết và liều thấp nhất gây chết $100 \%$. Những thay đổi về huyết học, sinh hóa máu, trọng lượng cơ quan tương đối, mô học cơ quan đã được ghi nhận trong thời gian thử nghiệm. Theo dõi tình trạng chung của chuột đến hết ngày thứ 14 sau khi uống thuốc thử lần đầu. Vào ngày thứ 15 , tất cả các con vật được gây mê bằng diethyl ete, các mẫu máu, mẫu mô của tim, gan, thận được thu nhận và gửi đến cơ sở xét nghiệm để phân tích và đọc kết quả. Các khuyến nghị được tuân theo về số lượng và giới tính của động vật được sử dụng [21].

\subsection{Kiểm tra các chỉ tiêu nghiên cứu}

\subsubsection{Kiểm tra thể chất}

Tất cả các động vật được quan sát hai lần mỗi ngày để đánh giá về tình trạng chung, các dấu hiệu lâm sàng và tỷ lệ tử vong trước khi thử nghiệm và trong suốt thời gian dùng cao chiết EtCA. Tất cả các động vật được cân riêng trước khi dùng thuốc thử vào ngày đầu tiên và mỗi tuần một lần sau đó [22]. Các thay đổi như khác nhau về ngoại hình, hành vi (buồn ngủ, tiết nước bọt, hôn mê) và bất kỳ chấn thương hoặc bệnh tật trong thời gian dùng thuốc, biểu hiện của độc tính và sự xuất hiện của các triệu chứng bất thường do thuốc thử sẽ được quan sát và ghi chép vào sổ cá nhân hàng tuần. Tỷ lệ tử vong, tình trạng nguy kịch và sự hiện diện, mức độ của các dấu hiệu bất thường được ghi nhận riêng cho từng nhóm điều trị [23].

\subsubsection{Huyết học và sinh hóa máu}

Chuột được nhịn ăn ít nhất 18 giờ trước khi giải phẫu, mẫu máu được thu thập từ đuôi. Máu toàn phần được cho vào ống Vacutainer có chứa chất chống đông K2-EDTA để chống đông máu [22]. Phân tích huyết học được thực hiện bằng máy phân tích huyết học tự động (Sysmex K-450, Nhật Bản) [18]. Thông số huyết học như số lượng hồng cầu $(\mathrm{RBC})$, hemoglobin $(\mathrm{HGB})$, bạch cầu (WBC), số lượng tiểu cầu (PLT) được ước tính $[22,24]$. Máu được thu thập trong các ống lấy huyết thanh chứa các hạt silicagen, thủy tinh và silicagen sẽ làm tăng tốc độ đông máu và ông $\mathrm{NaF}$ chứa thành phần Kali Oxalate và $\mathrm{NaF}$ (Kali Oxalate - chất chống đông bằng cách liên kêt $\mathrm{Ca}^{2+}$ của máu, $\mathrm{NaF}^{-}$chất ngăn cản quá trình đường phân, ngăn cho glucose trong máu không bị phân hủy). Các thông số sinh hóa máu được đo bằng máy phân tích sinh hóa huyết thanh (Hitachi 7020, HITACHI, Tokyo, Nhật Bản). Các chỉ tiêu sinh hóa được phân tích như protein, albumin, globulin, BUN, creatinine (CRE), axit uric [25].

\subsubsection{Trọng lượng tương đối cơ quan}

Vào ngày thứ 15 của quá trình thử nghiệm, tất cả các con chuột đều được gây mê bằng chloroform. Chuột sau đó được phẫu thuật, các cơ quan nội tạng (tim, gan, thận) được lấy ra và cân để tính trọng lượng nội tạng tương đối [25] và được quan sát để tìm tổn thương tổng thể [26]. Trọng lượng tuyệt đối của cơ quan của chuột được đo bằng cân điện tử (Marte - $\mathrm{AD} 2000$, tải trọng tối đa $210 \mathrm{~g}$; độ nhạy $0,01 \mathrm{~g}$ ) [27]. Trọng lượng tương đối của cơ quan nội tạng được tính theo công thức:

Trọng lượng nội tạng tương đối $(\%)$ = (trọng lượng nội tạng tuyệt đối $(\mathrm{g}) /$ trọng lượng cơ thể của con vật vào ngày phẫu thuật $(\mathrm{g})) \times 100[28]$

\subsubsection{Mô bệnh học cơ quan}

Các cơ quan như tim, gan, thận được cắt bỏ và cân đo cẩn thận. Các cơ quan này được bảo quản trong môi trường cố định có $10 \%$ formalin đệm để nghiên cứu mô bệnh học. Các phần parafin nội tạng được chuẩn bị, nhuộm bằng haematoxylin và eosin, quan sát dưới kính hiển vi ánh sáng [29]. 


\subsection{Xử lý số liệu}

Tất cả các giá trị được biểu thị dưới dạng $\mathrm{MEAN} \pm \mathrm{SD}$ và kết quả được phân tích thống kê bằng phân tích phương sai một chiều (ANOVA). Sau đó tiến hành thực hiện kiểm tra so sánh của Tukey bằng phần mềm thống kê Statgraphics Centurion XVIII, $\mathrm{P}<0,05$ so với đối chứng được coi là có ý nghĩa thống kê [30].

\section{KẾT QUẢ VÀ THẢO LUẬN}

\subsection{Kiểm tra thể chất}

Dựa vào triệu chứng lâm sàng ở các lô thí nghiệm cho thấy không có hiện tượng chuột chết. Sau 3 giờ cho uống chuột có dấu hiệu mệt mỏi nhưng sau đó đến 72 giờ thì nhận thấy chuột hoạt động hô hấp, chạy nhảy, ăn uống của chuột đều bình thường, lông chuột mượt, đi ngoài phân khô.

\subsection{Huyết học và sinh hóa máu}

Bảng 1: Ảnh hưởng của EtCA đến thành phần huyết học máu ngoại vi chuột trong thử nghiệm độc tính cấp tính

\begin{tabular}{ccccc}
\hline Chỉ tiêu & Đối chứng & $2000 \mathrm{mg} / \mathrm{kg}$ & $4000 \mathrm{mg} / \mathrm{kg}$ & $6000 \mathrm{mg} / \mathrm{kg}$ \\
\hline $\mathrm{RBC}\left(\mathrm{x} 10^{6} \mathrm{tb} / \mathrm{mm}^{3}\right)$ & $8,2^{\mathrm{a}} \pm 0,4$ & $7,9^{\mathrm{a}} \pm 0,5$ & $7,7^{\mathrm{a}} \pm 0,3$ & $8,1^{\mathrm{a}} \pm 0,4$ \\
\hline HGB $(\mathrm{g} / \mathrm{dl})$ & $12,5^{\mathrm{a}} \pm 0,5$ & $12,6^{\mathrm{a}} \pm 0,4$ & $12,5^{\mathrm{a}} \pm 0,6$ & $12,9^{\mathrm{a}} \pm 0,6$ \\
\hline PLT $\left(\mathrm{x} 10^{3} \mathrm{tb} / \mathrm{mm}^{3}\right)$ & $603^{\mathrm{a}} \pm 69$ & $605^{\mathrm{a}} \pm 51$ & $617^{\mathrm{a}} \pm 59$ & $641^{\mathrm{a}} \pm 66$ \\
\hline WBC $\left(\mathrm{x} 10^{3} / \mathrm{mm}^{3}\right)$ & $2,2^{\mathrm{a}} \pm 0,8$ & $2,6^{\mathrm{ab}} \pm 1,1$ & $2,9^{\mathrm{ab}} \pm 0,6$ & $3,8^{\mathrm{b}} \pm 0,4$ \\
\hline
\end{tabular}

Số liệu được trình bày dưới dạng Mean \pm SD. Các số mũ chữ cái khác nhau trong cùng một hàng biểu thị sự khác biệt có ý nghĩa của các nghiệm thức khảo sát theo kiểm định LSD ở mức độ tin cậy $95 \%$ và ngược lại.

Bảng 2: Ảnh hưởng của EtCA đến thành phần sinh hóa máu ngoại vi chuột trong thử nghiệm độc tính cấp tính

\begin{tabular}{ccccc}
\hline Chỉ tiêu & Đối chứng & $2000 \mathrm{mg} / \mathrm{kg}$ & $4000 \mathrm{mg} / \mathrm{kg}$ & $6000 \mathrm{mg} / \mathrm{kg}$ \\
\hline Protein tồng $(\mathrm{g} / \mathrm{dl})$ & $5,3^{\mathrm{a}} \pm 0,3$ & $5,1^{\mathrm{a}} \pm 0,2$ & $5,5^{\mathrm{a}} \pm 0,3$ & $6,5^{\mathrm{b}} \pm 0,1$ \\
\hline Albumin $(\mathrm{g} / \mathrm{dl})$ & $3,2^{\mathrm{a}} \pm 0,4$ & $3,1^{\mathrm{a}} \pm 0,5$ & $3,4^{\mathrm{a}} \pm 0,4$ & $3,4^{\mathrm{a}} \pm 0,4$ \\
\hline Creatinine $(\mu \mathrm{mol} / \mathrm{l})$ & $0,49^{\mathrm{a}} \pm 0,02$ & $0,48^{\mathrm{a}} \pm 0,01$ & $0,45^{\mathrm{b}} \pm 0,01$ & $0,47^{\mathrm{ab}} \pm 0,02$ \\
\hline Uric acid $(\mathrm{mg} / \mathrm{l})$ & $12,4^{\mathrm{ab}} \pm 0,2$ & $12,7^{\mathrm{c}} \pm 0,1$ & $12,6^{\mathrm{bc}} \pm 0,2$ & $12,3^{\mathrm{a}} \pm 0,1$ \\
\hline BUN $(\mathrm{mg} \%)$ & $15,7^{\mathrm{a}} \pm 0,3$ & $15,9^{\mathrm{a}} \pm 0,4$ & $15,4^{\mathrm{a}} \pm 0,2$ & $15,6^{\mathrm{a}} \pm 0,5$ \\
\hline
\end{tabular}

Số liệu được trình bày dưới dạng Mean $\pm \mathrm{SD}$. Các số mũ chữ cái khác nhau trong cùng một hàng biểu thị sự khác biệt có ý nghĩa của các nghiệm thức khảo sát theo kiểm định LSD ở mức độ tin cậy $95 \%$ và ngược lại.

Kết quả thử nghiệm độc tính cấp tính trong 14 ngày bằng chiết xuất ethanol quả thể nấm $C$. aspera đối với các thông số huyết học của chuột được thể hiện trong bảng 1 . Kết quả với hàm lượng 2000 và $4000 \mathrm{mg} / \mathrm{kg}$ EtCA không ảnh hưởng đáng kể đến bất kỳ thông số huyết học nào được khảo sát. Trong khi đó, ở nồng độ $6000 \mathrm{mg} / \mathrm{kg}$ chiết xuất đã làm tăng đáng kể $(\mathrm{P}<0,05)$ lượng WBC, khi so sánh với đối chứng. Tương tự, sự gia tăng đáng kể $(\mathrm{P}<0,05)$ về số lượng WBC. Tuy nhiên, sự gia tăng các thông số trên vẫn nằm trong mức giới hạn về lượng WBC của chuột Swiss albino. Ânh hưởng của điều trị cấp tính bằng đường uống với chiết xuất ethanol quả thể nấm $C$. aspera đối với các thông số sinh hóa huyết thanh của chuột được thể hiện trong bảng 2. Cao chiết nghiên cứu không làm thay đổi nồng độ Albumin, BUN và Uric acid huyết thanh ở các liều thí nghiệm 2000,4000 và $6000 \mathrm{mg} / \mathrm{kg}$ EtCA so với đối chứng. Mức protein tổng số trong huyết thanh dường như tăng $(\mathrm{P}<0,05)$ ở liều $6000 \mathrm{mg} / \mathrm{kg}$ bw EtCA. Trong khi mức độ Creatinin trong huyết thanh có dấu hiệu giảm ở liều $4000 \mathrm{mg} / \mathrm{kg}$ EtCA so với các lô thí nghiệm đối chứng. Những kết quả này phù hợp với báo cáo của Sook YH, et al (2011) khi thử nghiệm độc cấp tính của chiết xuất nước Coriolus versicolor trên chuột [31].

\subsection{Trọng lượng cơ quan tương đối}

Các tác nhân độc hại được biết là ảnh hưởng đến gan, thận, tim và làm suy giảm chức năng sinh lý của động vật thử nghiệm. Do vai trò chính của thận trong việc bài tiết các chất thải như urê và creatinin máu, cũng như khả năng lọc và tái hấp thu chất ngưỡng cần thiết của cơ thể như chất điện giải, mức độ của các thông số sinh hóa huyết thanh này có thể được sử dụng làm xét nghiệm chức năng thận [32]. Trong phần lớn các trường hợp, sự thay đổi trọng lượng cơ quan tỷ lệ thuận với tổng trọng lượng cơ thể. Do đó, chuột thử nghiệm thường được kiểm tra để xác định xem kích thước của cơ quan có thay đổi hay không, đặc biệt 
là so với tổng trọng lượng của động vật thí nghiệm như một dấu hiệu cho thấy tác động bất lợi của hóa chất đối với cơ quan đó. Kiểm tra vĩ mô cơ thể giải phẫu đối với tất cả các cơ quan nội tạng được nghiên cứu, cụ thể là dạ dày, ruột non, ruột già, lá lách, gan và thận để tìm bất kỳ thay đổi nào có thể xảy ra về vị trí, hình dạng, kích thước và màu sắc không cho thấy bất thường tổng thể. Trọng lượng nội tạng tương đối (tính bằng $\mathrm{g}$ trên $100 \mathrm{~g}$ trọng lượng cơ thể) của gan, thận và tim của cả nhóm dịch chiết được xử lý và nhóm đối chứng được thể hiện trong ở bảng 3 . Kết quả cho thấy không có sự khác biệt đáng kể nào được quan sát về trọng lượng cơ quan tuyệt đối và tương đối của nhóm chuột được uống EtCA so với nhóm chuột đối chứng. Kết quả nghiên cứu phù hợp với đánh giá của $A$ na $B B$ và cộng sự (2016) khi đánh giá mức độ an toàn sinh khối bột Coriolus versicolor hòa tan trong nước thử nghiệm trên chuột [33].

Bảng 3: Ảnh hưởng của EtCA trọng lượng tương đối của tim, gan, thận chuột trong thử nghiệm độc tính cấp tính

\begin{tabular}{cccc}
\hline Nhóm thí nghiệm & Tim $(\%)$ & Gan $(\%)$ & Thận $(\%)$ \\
\hline Đối chứng & $0,43^{\mathrm{a}} \pm 0,02$ & $7,82^{\mathrm{a}} \pm 1,19$ & $1,81^{\mathrm{a}} \pm 0,13$ \\
\hline $2000 \mathrm{mg} / \mathrm{kg}$ & $0,42^{\mathrm{a}} \pm 0,04$ & $7,83^{\mathrm{a}} \pm 1,25$ & $1,79^{\mathrm{a}} \pm 0,08$ \\
\hline $4000 \mathrm{mg} / \mathrm{kg}$ & $0,44^{\mathrm{a}} \pm 0,05$ & $7,85^{\mathrm{a}} \pm 1,88$ & $1,83^{\mathrm{a}} \pm 0,11$ \\
\hline $6000 \mathrm{mg} / \mathrm{kg}$ & $0,43^{\mathrm{a}} \pm 0,02$ & $7,88^{\mathrm{a}} \pm 2,01$ & $1,82^{\mathrm{a}} \pm 0,9$
\end{tabular}

Số liệu được trình bày dưới dạng Mean $\pm \mathrm{SD}$. Các số mũ chữ cái khác nhau trong cùng một cột biểu thị sự khác biệt có ý nghĩa của các nghiệm thức khảo sát theo kiểm định LSD ở mức độ tin cậy $95 \%$ và ngược lại.

\subsection{Phân tích hình thái ngoài và mô học cơ quan}

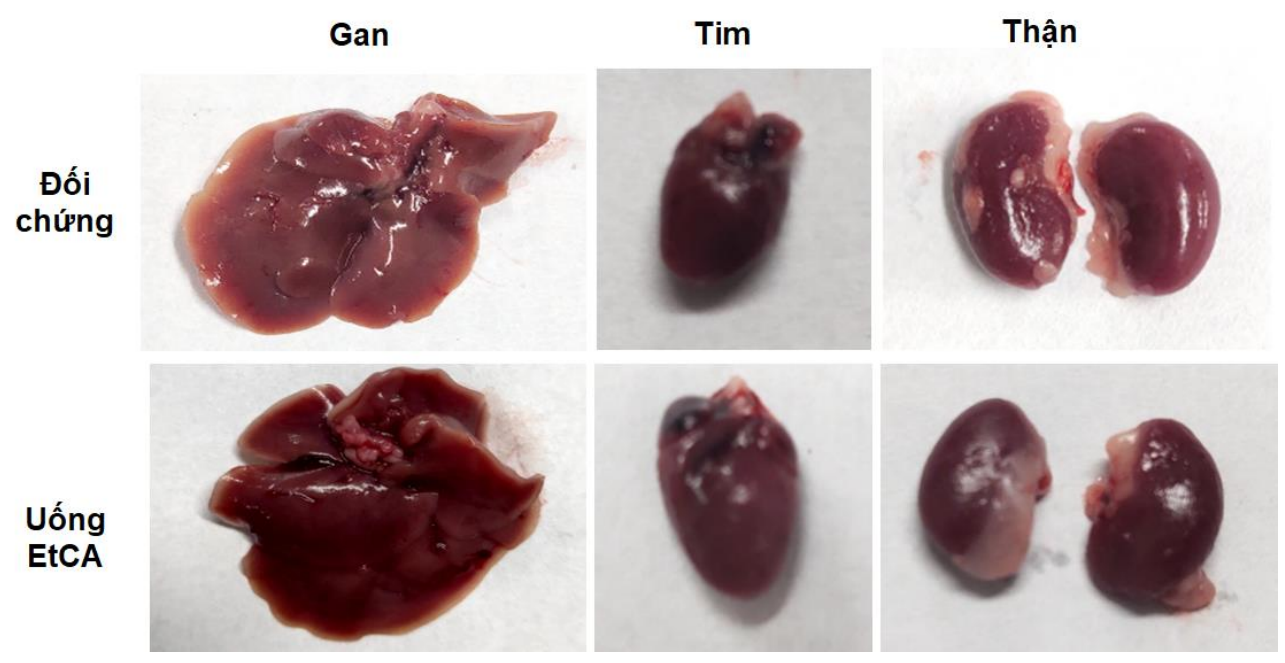

Hình 2: Hình thái đại thể gan, tim, thận của chuột nhóm chứng và uống EtCA.

Kiểm tra hình thái và mô học các phần gan, thận, tim của chuột được điều trị bằng chiết xuất 2000, 4000 và $6000 \mathrm{mg} / \mathrm{kg}$ bw EtCA (Hình 2 và 3 ) cho thấy cấu trúc bình thường của gan với sự xuất hiện bình thường của tĩnh mạch trung tâm và hình sin gan được lót bởi các tế bào nội mô và Kupffer tương tự như nhóm đối chứng. Các tế bào gan có kích thước và hình dạng bình thường, không có không bào nào được ghi nhận trong tế bào chất của chúng. Mặt khác, kiến trúc tiểu thùy bình thường của gan không bị ảnh hưởng; tế bào gan và tế bào Kupffer cũng bình thường. Ngoài ra, không có thay đổi liên quan đến điều trị về đường kính và hình dạng của các tĩnh mạch trung tâm, xoang gan và tĩnh mạch cửa. Đánh giá hình thái và mô bệnh học các phần thận của chuột được điều trị bằng EtCA trong 14 ngày ở liều uống 2000,4000 và $6000 \mathrm{mg} / \mathrm{kg}$ thể trọng cho thấy không có thay đổi mô bệnh học so với đối chứng. Mô học thận của cả động vật được điều trị đối chứng và chiết xuất cho thấy các đặc điểm bình thường, cấu trúc cầu thận và ống thận còn nguyên vẹn. Các búi mao mạch và kích thước của không gian Bowman cũng bình thường. Hơn nữa, các ống xoắn gần, ống lượn xa, quai Henle, ống góp, điểm vàng và tế bào trung bì dường như bình thường sau khi dùng cả hai liều so với thận đối chứng. Các đặc điểm mô học của tim cho thấy các tế bào tim bình thường với nhân nổi rõ, cấu trúc tế bào cơ tim và mô liên kết vẫn bình thường ở cả nhóm điều trị và nhóm chứng. Kết 
quả nghiên cứu phù hợp với đánh giá của Sook $\mathrm{YH}$, et al (2011) và Ana BB và cộng sự (2016) khi thử nghiệm độc tính cấp tính của chiết xuất nước Coriolus versicolor trên chuột [31, 33].

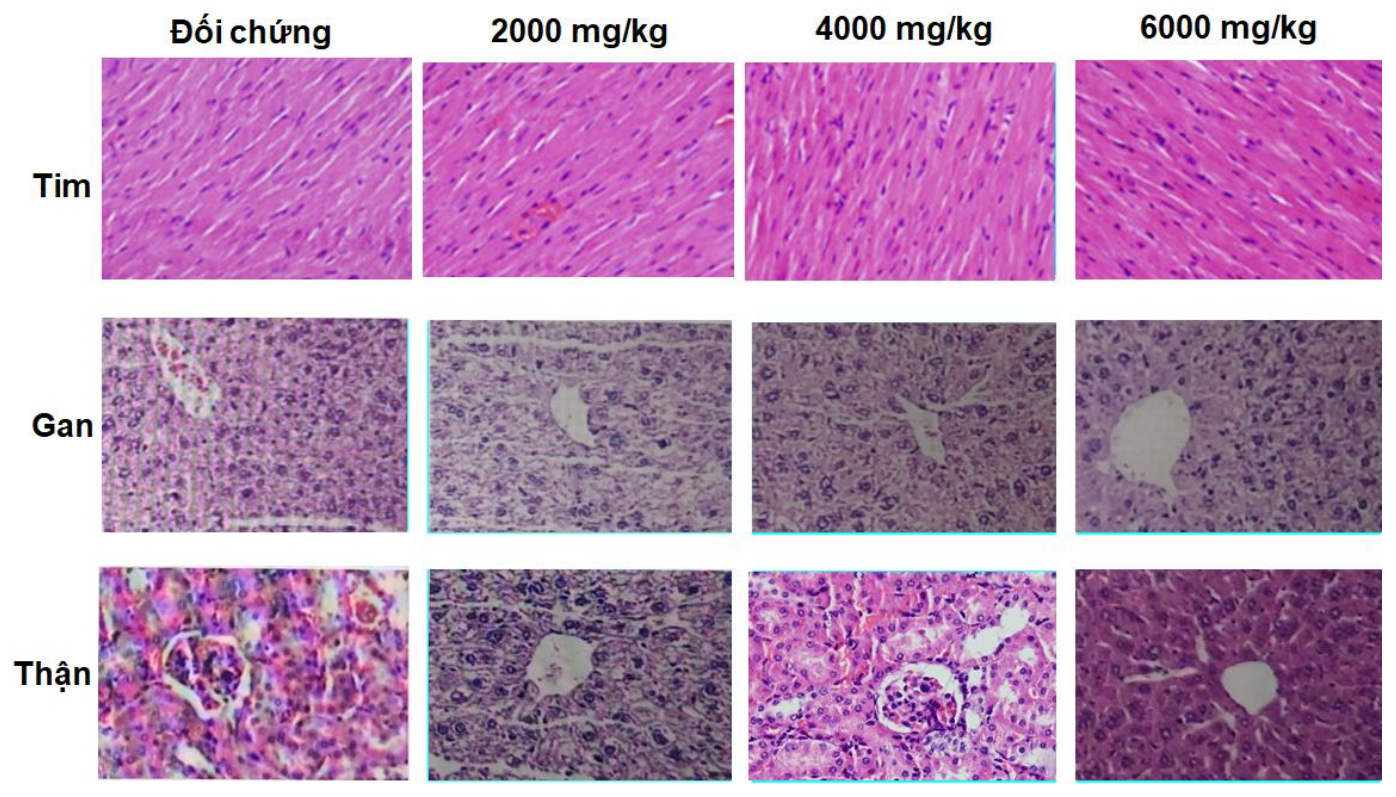

Hình 3: Mô bệnh học tim, gan, thận của chuột nhóm chứng và uống EtCA.

\section{KẾT LUẬN}

Kết quả đánh giá độ an toàn và điều tra độc tính cấp tính đối với chiết xuất ethanol quả thể nấm $C$. aspera cho thấy EtCA đã được thử nghiệm ở liều mức liều cao $(2000,4000$ và $6000 \mathrm{mg} / \mathrm{kg}$ thể trọng) trong 14 ngày không gây tác dụng phụ nghiêm trọng đối với sự phát triển cơ thể, trọng lượng cơ quan tương đối, các thông số huyết học, sinh hóa cũng như hình thái ngoài, mô bệnh học của tim, gan và thận ở chuột. Do đó, chiết xuất ethanol quả thể nấm $C$. aspera không có độc tính đối với chuột Swiss albino ở mức liều khảo sát.

\section{LỜI CẢM ƠN}

Các tác giả xin cảm ơn các đồng nghiệp và cộng sự từ Khoa Huyết học và Sinh hóa, Khoa Giải phẫu bệnh, Bệnh viện 175 Tp.HCM, Viện Pasteur Tp.HCM, Phòng Thí nghiệm Công nghệ Động vật Viện Công nghệ Sinh học và Thực phẩm, Trường Đại học Công nghiệp Tp.HCM đã hỗ trợ chúng tôi trong dự án này.

\section{TÀI LIỆU THAM KHẢO}

1. Justo, A. and D.S. Hibbett, Phylogenetic classification of Trametes (Basidiomycota, Polyporales) based on a five-marker dataset. Taxon, 2011. 60(6): p. 1567-1583.

2. Trịnh, T.K., et al., Báo cáo kết quả thực hiện năm 2008 dụ án" Điều tra co bản thành phần loài và xây dụng danh luc nấm Việt Nam (Mycoflora of Vietnam)": Đề tài NCKH. 2008.

3. Fakoya, S. and S. Folarin Oloketuyi, Antimicrobial Efficacy and Phytochemical Screening of Mushrooms, Lenzites Betulinus, and Coriolopsis Gallica Extracts. TAF Preventive Medicine Bulletin, 2012. 11(6).

4. Chen, L.-L., et al., Two new tremulane sesquiterpenes from a mangrove endophytic fungus, Coriolopsis sp. J5. Chinese Chemical Letters, 2017. 28(2): p. 222-225.

5. PUIA, I.C., et al., Characterization of Trametes versicolor: Medicinal Mushroom with Important Health Benefits. Notulae Botanicae Horti Agrobotanici Cluj-Napoca, 2018. 46(2): p. 343-349.

6. Kamiyama, M., et al., Antioxidant/anti-inflammatory activities and chemical composition of extracts from the mushroom Trametes versicolor. International Journal of Nutrition and Food Sciences, 2013. 2(2): p. 85-91.

7. Fagbohungbe, Y. and V. Oyetayo, Phytochemical and antioxidant properties of Trametes species collected three districts of Ondo state Nigeria. 2014.

8. Melappa, G., et al., Phytochemical analysis and in vitro antioxidant, antimicrobial, anti-inflammatory and cytotoxicity activities of wood rotting fungi, Trametes ochracea. Pharmacognosy Journal, 2015. 7(2).

9. Janjušević, L., et al., Trametes versicolor ethanol extract, a promising candidate for health-promoting food supplement. Natural product research, 2018. 32(8): p. 963-967. 
10. Ho, C., et al., Differential effect of Coriolus versicolor (Yunzhi) extract on cytokine production by murine lymphocytes in vitro. International immunopharmacology, 2004. 4(12): p. 1549-1557.

11. Nguyen, N.-T., et al., CHEMICAL COMPOSITION AND ANTIOXIDANT, ANTI-INFLAMMATORY, AND ANTICANCER EFFECTS OF EXTRACT FROM YUNZHI MUSHROOM (CORIOLOPSIS ASPERA) IN VIETNAM. Pharmacophore, 2020. 11(4).

12. Shephard, D.A., The 1975 Declaration of Helsinki and consent. Canadian Medical Association Journal, 1975. 115(12): p. 1191.

13. Lorke, D., A new approach to practical acute toxicity testing. Archives of toxicology, 1983. 54(4): p. 275-287.

14. Miller, L.C. and M. Tainter, Estimation of the ED50 and its error by means of logarithmic-probit graph paper. Proceedings of the society for Experimental Biology and Medicine, 1944. 57(2): p. 261-264.

15. OECD, 423-Guidelines for the testing of chemicals Acute oral toxicity-Fixed dose procedure, 2001, Animals.

16. Iserhienrhien, L. and N.P. Okolie, Acute and Sub-acute Toxicity Profile of Methanol Leaf Extract of Geophila obvallata on Renal and Hepatic Indices in Wistar Rats. 2020.

17. Saleem, U., et al., Acute oral toxicity evaluation of aqueous ethanolic extract of Saccharum munja Roxb. roots in albino mice as per OECD 425 TG. Toxicology reports, 2017. 4: p. 580-585.

18. Tsai, W.-C., et al., Toxicity evaluation of water extract of tissue-cultured Taraxacum formosanum by acute, subacute administration, and Ames test. Electronic Journal of Biotechnology, 2020.

19. Kouadio, J.H., et al., Acute and sub-acute toxicity of aqueous extract of Nauclea latifolia in Swiss mice and in OFA rats. Tropical Journal of Pharmaceutical Research, 2014. 13(1): p. 109-115.

20. Pal, R.S. and A. Mishra, Evaluation of Acute Toxicity of the Methanolic Extract of Dhatryadi Ghrita in Wistar Rats. The Open Pharmacology Journal, 2019. 9(1).

21. Olaya, M.D.P., et al., Evaluation of the acute and subchronic oral toxicity of ethanol extract from Valeriana pavonii species in Wistar rats. Colombia Médica, 2010. 41(3): p. 256-266.

22. Lee, M.-J., et al., A 90-Day Repeated Oral Dose Toxicity Study of Alismatis Rhizoma Aqueous Extract in Rats. Toxicological research, 2019. 35(2): p. 191-200.

23. Ha, A.W., et al., Acute and subacute toxicity evaluation of corn silk extract. Preventive nutrition and food science, 2018. 23(1): p. 70.

24. Yuet Ping, K., et al., Acute and subchronic toxicity study of Euphorbia hirta L. methanol extract in rats. BioMed research international, 2013. 2013.

25. Das, N., et al., Evaluation of acute and subacute toxicity induced by methanol extract of Terminalia citrina leaves in Sprague Dawley rats. Journal of Acute Disease, 2015. 4(4): p. 316-321.

26. Yan, Y., et al., Toxicity study of ethanol extract from Oroxylumindicum (L.) Vent in rats. Journal of Traditional Chinese Medicine, 2018. 38(5): p. 714-725.

27. Silva-Santana, G., et al., Compared Anatomy and Histology between Mus musculus Mice (Swiss) and Rattus norvegicus Rats (Wistar). Preprints, 2019.

28. Aniagu, S.O., et al., Toxicity studies in rats fed nature cure bitters. African Journal of Biotechnology, 2005. 4(1): p. 72-78.

29. Bigoniya, P., T. Sahu, and V. Tiwari, Hematological and biochemical effects of sub-chronic artesunate exposure in rats. Toxicology reports, 2015. 2: p. 280-288.

30. Porwal, M., N.A. Khan, and K.K. Maheshwari, Evaluation of acute and subacute oral toxicity induced by ethanolic extract of Marsdenia tenacissima leaves in experimental rats. Scientia Pharmaceutica, 2017. 85(3): p. 29.

31. Hor, S.Y., et al., Acute and subchronic oral toxicity of Coriolus versicolor standardized water extract in SpragueDawley rats. Journal of ethnopharmacology, 2011. 137(3): p. 1067-1076.

32. Adedapo, A.A., M.O. Abatan, and O.O. Olorunsogo, Effects of some plants of the spurge family on haematological and biochemical parameters in rats. Vet Arhiv, 2007. 77(1): p. 29-38.

33. Barros, A.B., J. Ferrao, and T. Fernandes, A safety assessment of Coriolus versicolor biomass as a food supplement. Food \& nutrition research, 2016. 60(1): p. 29953.

Ngày nhận bài: 01/11/2020

Ngày chấp nhận đăng:28/01/2021 